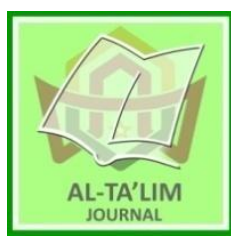

\title{
The Transformative Leadership of School Principal Paradigm in Developing Students' Religious and Social Characters
}

Received: 24 ${ }^{\text {th }}$ July 2019; Revised: 05 ${ }^{\text {th }}$ August 2019; Accepted: $26^{\text {th }}$ November 2019

Permalink/DOI: http://dx.doi.org/10.15548/jt.v26i3.581

Hamlan Andi Baso Malla*)

Institut Agama Islam Negeri Palu Sulawesi Tengah Indonesia

E-mail:hamlan@iainpalu.ac.id

\section{Khaeruddin Yusuf}

Institut Agama Islam Negeri Palu, Sulawesi Tengah, Indonesia

E-mail:khaeriiui@gmail.com

\section{Tahir Sapsuha}

Institut Agama Islam Negeri Ternate, Maluku Utara, Indonesia

E-mail: tahir_sapsuha@yahoo.com

\author{
Misnah \\ Universitas Negeri Tadulako Sulawesi \\ Tengah, Indonesia \\ E-mail: misnah@untad.ac.id
}

\section{*) Corresponding Author}

\begin{abstract}
The objective of this research aims to inestigate the transformativeleadership of school principal paradigm in developing the religious and social character of students at SMA Model Palu, Central Sulawesi. This research uses qualitative proposed by Bogdan dan Taylor. The technique of data analysis uses Miles and Huberman qualitative data analysis. The results indicate that, first, transformativeleadership of school principal paradigm is able to build commitment and cooperativeness in making changes, development, and improvement of the learning quality, management of educational quality administration that produces outstanding students. Second, it is able to develop a religious and social culture in changing the thinking and attitude paradigm of students who are obedience to God, honest, sincere, and have a social character in developing the students' attitudes on cooperativeness, cooperation, brotherhood, empathy, and tolerance. The development of religious and social personalities is carried out in an integrated manner through curricular and extra-curricular activities
\end{abstract}

Keywords: Transformative leadership; religious and social characters; attitude.

How to Cite: Malla, H., Yusuf, K., Sapsuha, M., \& Misnah, M. (2020). The transformative leadership of school principal paradigm in developing students' religious and social characters. Al-Ta Lim Journal, 26(3). doi:http://dx.doi.org/10.15548/jt.v26i3.581

\section{INTRODUCTION}

One of the leading high school levels in Central Sulawesi is SMANegeri Model Madani Palu. This school is an excellent school because it has a number of achievements and quality standards have been well organized. This can be seen in the achievement indicators of students who won various competitions in the quiz championship subjects at the high school level in Central Sulawesi and olympiad competitions in subjects at national and international levels. Another achievement is that annually, SMA Model Madani is able to produce $100 \%$ graduation on national examinations.

Achievements reached by SMA Negeri Model Madani Palu gradually increases for both academic achievement and non-academic achievements through fostering 
the religious and social character of students which is developed through classroom instructional learning and character building through extracurricular activities.

Various activities held at SMA Negeri Model Madani Palu are spiritual development activities, red cross activities, scout activities, social service activities, environmental care activities under the guidance of teachers. The activity aims to train and foster the spirituality and social interaction of students both in the school environment and the community environment (observation on august 23, 2018).

Personality fostering as a school effort to develop the religious and social potential of students by using a spiritual and social approach to produce a generation that has a religious and social attitude, they obey the religious education, and they also have an open attitude in communicating and interacting with fellow students, teachers, and the community. The efforts of personality development are carried out integrally on the cognitive, affective and psychomotor aspects of students.

Integration between cognitive, affective and psychomotor development is carried out in subjects, teachers focus on carrying out their duties and functions as educators, instructors, mentors, and coaches by integrating cognitive dimensions in the scientific field, psychomotor dimensions as a basis in implementing life skills and affective dimensions as a spiritual and social foundation in the formation of the personality of students.

In this context, the development of the religious and social personality of students is implemented not only in religious education subject but in all subjects as a response to the demand for fostering students, teachers transform learning by developing learning objectives, subject matter, methods, as well as an integrated learning evaluation system of affective, cognitive and psychomotor dimensions.
This was done in response to national demands mandated in Law No. 20 of 2003 concerning the National Education System, Government Regulation Number 19 of 2005 which has been changed to Government Regulation Number 32 of 2013 concerning National Education Standards and considers the demands of the 2013 curriculum which emphasizes the formation of balanced and continuous character, knowledge and skills of students.

The efforts made by the school principal in developing the religious and social personality of students are inseparable from the school principal's leadership model in making changes to the education system in schools. This change was seen in school planning in implementing the school's vision and mission towards an excellent and noble school.On the aspects of the 2013 curriculum implementation, the school principal of SMA Negeri Model Madani Palu in Central Sulawesi established a policy on the implementation of the 2013 curriculum which emphasized on the objectives of learning, developing subject matter which takes into account the characteristics of multicultural students, establishing learning methods and strategies relevant to the conditionsand set learning evaluation standards. The components of syllabus and lesson plan that accommodate the development of religious and social culture for students through intracurricular and extra-curricular activities

School principal leadershipwho tends to want changes in carrying out the duties and functions of leaders, educators, supervisors, and administrators as a feature of transformativeleadership.According Zwell (2000), principal leaderships are competencies that relate specifically to the management, supervision and development of people.Sandberg (2000); Spencer \& Spencer (2008) suggests that principal leadership is a fixed statement of behavior that shows the results achieved in work.In this context, Perda stated that the school principal was the main factor whether a change was successful or not, so that activities to improve, to elevate the 
program and learning process in the school is in the leadership of the school principal.

According to Perda, the school principal has roles and responsibilities as education leaders, education managers, education administrators and education supervisors who are given the task of planning, organizing, coordinating and finding strategies in developing educational resources owned by the school in order to unite in implementing and controlling the process and educational results(Ikhwan, 2018). The implementation of the duties and functions of the school principal will be carried out professionally and functionally if the school principal has a transformativeleadership paradigm.

Leadership is the ability to step out of existing culture and begin the process of more adaptive evolutionary change. The developers of the transformative theory argue that leadership means harmonizing, creating and empowering. Leaders transform the organization by aligning human and other resources and creating an organizational culture that fosters expressions of ideas freely and empowers people to contribute to the organization (Danim, 2006, Muhaimin, et al, 2009).

Various studies conducted by academics about transformative leadership such as Northouse in his book Leadership: Theory and Practice which propose various approaches in leadership, namely the natural approach, skills approach, situational approach and leadership theories. In addition, Setiawan, et.al in his book Transformative Leadership: Illustration in the Field of Educational Organizations which states the urgency of transformative leadership with the type,behavior, and typology of leadership carried out by a leader in an educational organization.

The study of transformative leadership is different from the study of this paper. The difference is in the dimensions of the development of the religious and social personality of students at school. This study aims to investigate the transformative leadership paradigm of school principals in the development of religious and social personalities to change the philosophy of life with the values of honesty, togetherness, tolerance, and empathy for students in SMA Negeri Model Madani, Palu, Central Sulawesi.

\section{METHOD}

This study uses qualitative methods proposed by Bogdan and Taylor (1975), a research method that produces descriptive data in the form of written and oral words from people and observable behavior.Qualitative methods emphasize the meanings that are interpreted in the descriptive form of data obtained from informants from interviews, observations and document sources. Interviews were conducted to informants, namely the school principal, vice-school school principals, teachers and students carried out in the form of semistructured. Interviewer raises questions to get direct, complete and in-depth resources about school principals' leadership in fostering the religious and social culture of students.

The non-participant observation technique is used in direct observation in Model Madani High School about phenomena or events relating to policy making and the implementation of the school principal's leadership to the school component in fostering the religious and social culture of students. Sources of data were obtained using primary data obtained at SMA Model Madani related to the school principal's policy document on extracurricular and extracurricular activities in fostering religious and social character of students

Data from interviews, observations and documents were analyzed using data reduction techniques, display data, and data verification proposed by Milles and Huberman (2005). The phase of data analysis and interpretation is a process of understanding the meaning of a series of data that has been described in obtaining research findings of the school principal's 
transformative leadership in fostering religious and social personality and finding paradigm shifts in thinking and behaving of students at SMA Model Madani Palu, Central Sulawesi.

\section{RESULT AND DISCUSSION}

SMA Negeri Model Madani Palu, Central Sulawesiis a school founded by Prof. Aminuddin Ponulele, MS as Governor of Central Sulawesi and Dra. Hj. Uhra Lamarauna, M.Sc as the Head of the Central Sulawesi Provincial Education Department in 2004, it was inaugurated on August 18, 2005, with the National School Number 40203776 and NSS 301186003024. The school received funding from the Provincial Regional Budget (APBD) and guidance from the Education and Culture Department of Central Sulawesi Province. Since its inception in 2004 until 2019 this school has been led by 5 (five) different school principals, namely; Drs. Ahlan Lamuhido, M.M also as Head of the secondary and high education section, Provincial Education and Teaching Department in 2005-2006; Drs. Zulkifli Radjamuda, M.Ed as acting on duty in 20062007; Drs. H. Ibrahim Janat, M.Pd, 20072011, Drs. Zulkifli Radjamuda, M.Ed as acting school principal of 2011-2012; Anas Syakir, M.Pd. in 2011-2017; and Drs. Abd. Kadir, M.Pd 2017 - now. Under the leadership of those school principals, various achievements that have been obtained by schools at the provincial, national, and international levels and it was awarded of Pilot International Standard School (RSBI) from the Education Directorate of the Ministry of National Education in 2010/2011.

This school was established in order to produce graduates of civil society who have a balanced advantage between science and technology, ethics, morals who have national and international insights. This goal is used as a vision of the SMA Negeri Model Mandani, namely the realization of superior human beings in the field of science and technology based on faith and piety (imtaq), ethics, morals and caring for the environment and having national and international insights.

This vision is described in the school's mission, namely (1) preparing and implementing an active, creative, innovative, effective, efficient and enjoyable learning process to achieve national and international reputation; (2) encourage achievement of language competencies, creative economies, and international school atmosphere;(3) participate in all types of academic and nonacademic competitions to achieve a national reputation. (4) develop intellectual, emotional, social and spiritual intelligencepotential; (5) developing the artistic interest, cultural and sports creativity; (6) applying religious values, democracy, human rights in everyday life; (7) implementing school-based management in managing schools by synergizing the three main stakeholders, namely the government, private and community.

From the school's vision and mission, it is determined the purpose of the SMA Negeri Model Madani are to obtain school exam scores and national exams with category A, obtain national and international reputation in English debates, science, and research olympiad.Educators, education supporting staff and students who are able to speak English fluently, to have a healthy school cooperative, to have a clean, green and beautiful school environment, to have professional teachers, to haveexcel students who areable to integrate sciences, who are virtuous, religious, and independent. In addition, the school has an art and sports team, applies religious values, democracy and upholds human rights to the school community in daily lives and it implementsschool-based management and managing schools with an online system, it has standard facilities and infrastructure in accordance with national education standards and teacher standards with sister schools in domestic and overseas. Furthermore, and to alter school status from National Standard School (SSN) to Pilot International Standard Schools (RSBI)) (Profil SMA Madani, 2018). 
To achieve the vision, mission and objectives of SMA Negeri Model Madani, the school principal made several strategic steps namely (1) designing a school program based on the vision, mission and goals of the school through a system of deliberation with all components of the school; (2) synergizing the application of the curricular learning system in the classroom, co-curricular learning and extracurricular learning; (3) optimizing teaching staff in fostering the potential of students; .(5) implementing quality learning with the A grade standards for school examinations and national examinations, (6) synergizing the implementation of schoolbased management with the government, private sector and school committees, (7) conducting coaching and training programs for outstanding students to participate in national and international olympiads , (8) carry out an integration program to foster religious, social and nationalism personality (Feri, 2019).

In planning and implementing the program, the school principal of SMA Negeri Model Madani applies a democratic leadership with the paradigm of a transformative model involvingeducators and education supporting staff to discuss and establish programs and carry out school activities through consensus meetings in school meetings. Academic and non-academic activities in schools are carried out with the commitment and togetherness of the school principal along with the vice-school principals and all teaching staff and education staff in accordance with the results of the school meeting.

Transformative leadership is one model of leadership that requires system change within an organization. Educational organizations need development and change, this can be done if educational organizations pay attention to two things, namely leadership and school culture. Leaders in educational organizations can manage the changes they will experience and the risks that will be borne as a result of the change. A fundamental change in the organization of education is building a culture of learning organizations, namely an organization managed by leaders who always create systems and make people in organizations able to develop themselves sustainably (Muhaimin, at al, 2009).

On the basis of the application of the school principal's transformative leadership in implementing school programs, SMA Negeri Model Madani Palu has succeeded in obtaining academic and non-academic achievements. A number of academic achievements that have been achieved are participating in Indonesia National Science Olympiad at national and international levels.

From 2015 to2007, SMA Negeri Model Madani has collected 5 national and international ScienceOlympiad medals consisting of 1 gold medal in the field of earth and 4 bronze medals in the fields of economics and earth.The National Science Olympiad activities attended by students in the fields of physics, biology, chemistry, mathematics, economics, earth, astronomy and computers. The greatest achievement of SMA Negeri Model Madani Palu was being the participants in the international level science academics in the field of earth which, SMA Negeri Model Madani 'Fraga Fahmi' representing Indonesia in the International Earth Science Olympiad (IESO) in Taiwan by winning bronze (bronze) and the best corporation medals.

Feri (2019) stated that the same opinion that the school principal of Palu State High School Madani had to establish a coaching and training program for students to take part in national and international science olympiad, this program was designed and carried outthrough consensus. School principal leadership who always innovates change with the transformation paradigm can motivate teachers to foster and train outstanding students in the academic field at national and international levels as an effort to implement the vision and mission and goals of schools that are national and international.Susanto (2018) argues that transformative leadership is a leadership that 
is able to bring about change in individuals and for organizations to achieve higher performance. A transformational leader must be able to carry out his duties and functions to realize the vision of his members in empowering existing resources.Transformational leaders as an agent of change and act as a catalyst that is giving the role of changing the system in a better direction(Komariah \& Triatna, 2006).

The school principal of SMA Negeri Model Madani Palu is not only trying to achieve achievements in the academic field but also making efforts in terms of nonacademic coaching, integrating fostering religious, social and nationalism values in developing the personality of students. Personality development of students with the contents of religious and social values is carried out in various religious activities and social services in schools and in the community through planning in school heads' meetings, vice-school principals, educators and appointing. Iswanto Feri as the coordinator of personality development programs that is the activities of building faith and piety of the students.This statement corresponds tothe initial idea of transformational leadership was developed by James McGregor Burns who applied it in a political context. In an organizational context developed by Bernard Bass and Ronald E. Reggio, thetransformational leaders help followers grow and develop into leaders by responding to individual followers by empowering them and by aligning the objectives and goals of individual followers, the leader, the group, and the larger organization. More evidence that we can translate to leadership expectations and commitment to the group and organization (Bernad M. Bass \& Ronald E. Riggio, 2006).

The appointment of the coordinator of personality development faith and taqwa as an effort to provide and instill religious, social, nationalism, democracy and human rights values to students and the development of the potential for spiritual, intellectual, emotional and social intelligence as well as fostering the development of interest in artistic, cultural interest and sports in the school environment and in the community. In its implementation, the school management is developed through the implementation of school-based management by synergizing three main forces, namely the government, the private sector, and the community to develop schools in academic activities and non-academic activities (Indarti, 2017).

Transformative leadership of school principalis to make changes through delegation of authority to subordinates in structuring the school systemin accordance with the main tasks and functions of subordinates, namely the vice-school principals on the curriculum and public relations affair, the vice-school principals for student affairs and school facilities,Delegation of authority is also assigned to the teamwork by involving teachers and committees representing the community established by the school principal to develop school programs to achieve the school's vision and mission (Mahluddin, 2019).The established teamwork consists of vice-principals, teachers and school committees represented the community, formulated concepts, planned, determined the implementation of activities and evaluations through deliberations held based on the teamworkagenda. These steps are very effective in developing and establishing an excellent school and advanced in academic achievement and development of the religious and social personality of students.

Setiawan (2013) stated that transformative leadership of school principal paradigm is leadership behavior that makes human-led resources inspired by everyone that grows from him, this inspiration needs to be used as an approach to influence and mobilize educational organizational components, without intimidation and authoritarian behavior as the main drivers of educational organization, but behavior transformative leaders with positive ways of thinking, say the right things, be able to simplify problems, have the ability to identify 
the core issues, and understand the psychology of educational organizations.Bass's opinion in Susanto that transformational leadership is the influence of leaders on employees who are led. Employees feel a sense of trust, pride,loyalty, and respect for superiors and they are motivated to do more than expected (Susanto, 2018).

The behavior and characteristic of transformative leaders are very significant in driving change, growth, and development of educational organizations.Baharuddin, et.al, (2012) stated that there are four characteristics that must be possessed by a leader. First, attention management is the ability to communicate goals and directions that can attract the attention of members of the organization. Second, the management of meaning is the ability to create and communicate the meaning of goals clearly and achievable. Third, trust management is the ability to be trusted and always consistent so that people will listen to them. Fourth, selfmanagement is the ability to know, master and control themselves within the boundary of their strengths and weaknesses. The same statemen by Amstrong, (2009) Armstrong"s Handbook Of Management And Leadership: a Guide To Management For Result.

The four characteristics of leaders are relevantto the leadership of the head of SMA Negeri Model Madani, namely having; (1) attention management, it is the ability to communicate the vision, mission, goals and school programs to the school components to be carried out together, (2) management of meaning is the ability to communicate to school components about clear meaning and purpose in the desired direction by the school, (3) trust management, namely the ability of the principal to communicate school programs, delegate tasks and job responsibilities according to the results of agreements in the deliberations to be carried out by subordinates with a sense of responsibility. (4) self-management, it is the ability of the principal to increase selfcapacity, control themselves, understand and master tasks and functions, and can communicate to subordinates in order to master the work, carry out work according to tasks and functions and be able to control themselves as a form of emotional intelligence carry out work.

Bass and Aviola in Komariah (2006) suggest that there are four dimensions of transformational leadership, namely. first; idealized influence is a behavior that generates respect and confidence from the person they lead and has the meaning of sharing risks through consideration of employee needs above personal needs and ethical moral behavior. second; inspirational motivation is reflected in behavior that always provides challenges for the work done by employees and gives meaning to the spirit of arousing enthusiasm and optimism, enthusiasm and hope. third; intellectual stimulationnamely leaders who practice innovation. Leadership attitudes and behavior are based on the knowledge that intellectually is able to translate it into productive performance. fourth; individually consideration namely the leader reflects himself as a person who is attentive in listening to and following up on complaints, ideas, expectations and all input submitted by employees by providing assistance, providing services, examining individual needs for development and increasing success.

The ability of school principals to manage human resources is very important to optimize the implementation of school programs in academic and non-academic skills. The implementation of academic programs is carried out in classroom learning activities according to curriculum components including aspects of learning objectives, study materials, learning methods and evaluation of learning on subjects, and improving the quality of management of educational administration by education supporting staff through cooperation, togetherness and mutual respect for performance in accordance with basic tasks and each function.Non-academic program activities are carried out in cocurricular and extracurricular activities to foster the personality of students. Personality 
coaching is carried out aimed at fostering student morals and ethics in the religious and social dimensions carried out in an integrated manner at SMA Negeri Model Madani Palu.

The four dimensions of transformative leadership provide respect and ethical behavior, arouse enthusiasm, motivation, and hope for subordinates, have knowledge that is intellectually capable of improving productive performance and reflects itself as someone who can provide assistance and service, can influence subordinates in carrying out tasks and functions for the success of individuals and organizations. This is in accordance with Muhaimin et.al's (2009) view that leaders are able to give influence to others to carry out what is desired by the leader towards a more effective and efficient goal.Transformative leadership theory sees that leaders have the task of harmonizing, creating and civilizing. Leaders carry out the transformation of the organization by harmonizing human resources and other resources, creating an organizational culture that encourages the expression of ideas freely and empowers people to contribute to the organization, so that leaders are referred topeople who can influence others (Aminuddin, 2017).

Personality development that is more popular with the term personality development is "a constructive process of good qualities of someone and reduce his bad qualities, how to control yourself, foster trust in him, shape his image, how to communicate and others. Personality is also interpreted as a special disposition that can be directed, taught and applied by each individual who can be pursued through training or education, courses that train and teach about personality development. This can be done "externally" concerning appearance, etiquette, posture, skills, outward beauty, and personality from "in" concerning life attitudes, ways of thinking, so on(Sanimbar \& Anira, 2016).

One of the form of the personality and social development program is training the students for delivering Friday sermons and provide opportunities for students to practice itin school mosques, inviting religious speakers to develop religious insights, carrying out religious holidays without distinguishing religion held by students, carrying out social service to the communities at villagesor sub-districts which integrates religious and social activities and visits orphanages to donate the needs of orphanages.

Personality is a trait as a potential possessed by someone who is personal both formed naturally from birth and as an influence of the environment. Therefore, personality can be developed through education as a systematic effort to change the mindset and pattern of attitudes towards human beings who have good character. It seems that there are differences in the meaning of self-development and personality development. Personality development is interpreted more closely with ethical meanings and it discusses ethics, politeness, behavior inlife-related to appearance (physical appeal) and it is useful for obtaining jobs and maintaining appearance in society.

Abraham Maslow sited by Rusdianto (2015) that personality development is a process of behavior change,modesty, the character of each individual who is functional for individual and social interests in the community, therefore personality can be changed through educational processes. Factors that further determine the form ofthe personality of a person is the result of the learning process, both the learning process without realizing it as an adjustment to the environment and intentional or planned learning outcomes from various experiences. The form of personality can be seen through the quality of a person's overall behavior. Personality development is an effort in managing the internal aspects of oneself, one's inner attitudes and aspects of external selfbehavior is the way individuals present themselves oris the appearance of someone in the perceptions of others. Every individual is able to be proactive to increase selfawareness, self-knowledge, self-intelligence, self-identity, talent and potential, self-quality, 
and fulfill life goals with a clear vision and have a superior personality to take responsibility for personal health, career, finance, relationships, emotions, habits, and beliefs in the values of life that each individual strives for in an individual effort and process in the education system.

The education system is designed to guide and develop the intellectual, emotional, social and spiritual intelligence of students. It is expected that each individual has spiritual piety and social piety characterized by values of affection, sincerity, responsibility, honesty, sacrifice, obedience, discipline, shame, respect, appreciation, glory, humility, love of nature and nationalism. These values become the culture and character of the nation. Activities, programs, and school environment must teach students about the main values, so that they do not only know about good and bad things, but they practice those values in their daily lives and in school interaction (Jejen, 2017).

Student personality development aims to develop students' self-potential internallywhich teaches values in the religious spiritual dimension and develops selfpotential externally in producing religious, social, interrelated relationships between individuals and other human beings in the spirit of maintaining the personal values of students.

Co-curricular and extracurricular activities are school programs that have an influence on personality development, changes in attitudes and behavior of students according to religious values and social values. Religious values in students are seen in obedience in carrying out religious teachings such as congregational prayers in school mosques, respect for teachers and other school civitates, mutual respect for fellow students without distinguishing each other, tolerance towards ethnic differences, religion, race and between groups, have social sensitivity to help each other (Abdul Kadir, 2018).
The religious and social values of the students are as stated in Law Number 20 of 2003 concerning the National Education System that education is a conscious and planned effort to create a learning atmosphere and learning process so that students can actively develop their potential, have spiritual, religious, self-control, personality, intelligence, noble character, life skills that will be useful for him, society, nation and country. Students have a personality in the life of the community, nation, and state instilled the habit of thinking and scientific behavior that is critical, creative and independent to students in learning activities in the classroom and curricular and extracurricular activities in the school environment and in the community.

Education raises social awareness in shared life to develop social relations, togetherness, and brotherhood both in the school environment and community environment. The process of self-recognition is the beginning of the growth of a sense of self-esteem, togetherness, and attachment (sense of solidarity), a sense of belonging, and a sense of belonging, a sense of pride towards self-potential to be actualized in achieving goals. Such education can affect a very large impact on students in the formation of religious and social personalities in individuals, the social environment and the Indonesian people.

This is relevant to the development of school programs according to the vision, mission, and objectives of SMA Negeri Model Madani, which is to develop the potential for intellectual, emotional, social and spiritual intelligence. fostering the interest of creative arts, culture, and sports, applying religious values, democracy, human rights to school people in their daily lives in schools and the community.

The religious values developed at the SMA Negeri Model Madani Palu are the cultivation of faith in the Almighty God, obedience to worshiping the Almighty God, loving the Prophet, humanitarian values and multicultural values respecting fellow human 
beings regardless of differences. Values are not only taught by teachers on a subject but instill religious values through exemplary, habituation in behavior and practices of worship (Kartini, 2019).

Social values developed in SMA Negeri Model Madani Palu are participation, partnership (friends), cooperation, collaboration, responsibility (empathy) and life harmony (tolerance). These values are taught in historical education subjects as one of the fields of social science and practiced in social activities in schools and in the community such as giving social assistance to orphanages and raising funds to help needy communities in rural areas (Hasni, 2019).

The development of religious values and social values is carried out in an integrated manner, religion teachers besides instilling religious values also inculcate social values, as well as teachers of social science studies who instill social values and religious values. Both of these values are implemented in religious education and history education subjects in classroom learning and in school extracurricular activities that have implications for religious personalities in the form of obedience to worship, honesty, sincerity, tolerance, togetherness and social personality in the form of togetherness, cooperation, brotherhood and empathy for others. The guidance of SMA Negeri Model Madani students both in intra-curricular and extracurricular activities to create students who have science, technology and art that are integrated with religious values, social values, skills and maintenance of the environment (ecology) on the personal learners.

\section{CONCLUSION AND RECOMMENDATION}

The school principal implements transformative leadership by making changes to the system of academic and non-academic activities through several steps: first, optimizing human resources for educators and education personnel according to their respective main tasks and functions; second, developing school programs based on the vision, mission and goals of the school; third, delegating authority to subordinates and teamworks in carrying out activities according to the results of deliberations; fourth, conduct monitoring and evaluation as a control system for every school program and activity that is being carried outand has been implemented. The school principal's efforts are effective in achieving the success of the school's vision in producing civil society graduates who have a balanced advantage between science and technology, ethics, morals that with national and international insights

School principal leadership in the development of religious personalities is carried out through curricular activities in the classroom that are integrated with subjects and extracurricular activities in non-academic activities through fostering faith and piety. Faith and piety activities in schools include congregation prayer programs at the school mosque. train students to preach and deliver sermons on Friday Prayer. Furthermore, the school principal delivers sermons to students. In addition, the school carries out religious activities. Religious activities affect students' personal development so that they become believers, obey religious rituals, have values of honesty, togetherness, and tolerance towards multicultural and multifaith fellow.

School principal leadership in the development of social personality is carried out in extracurricular and extracurricular activities that are integrated with religious formation activities. This activity was carried out in schools and community environments in rural areas such as social service activities and visits to orphanages to instill the value of empathy, care for others, build social relations. Social coaching affects the social personality of students to be humanistic, respectful and helpful individuals without distinguishing the social and economic status of fellow students.

\section{REFERENCES}

Aminuddin, M. Yusuf. (2017). Model Kepemimpinan Transformatif (Kajian Kepemimpinan Transformatif Di 
Lembaga Pendidikan Islam). $A l$ Hikmah: Jurnal Studi Keislaman, 7(2), 14-33.

Amstrong,Michael. (2009). Armstrong"s Handbook Of Management And Leadership: a Guide To Management For Result. London: kogan Page.

Bahanuddin dan Umiarso. (2012). Kepemimpinan Pendidikan Islam, Antara Teori dan Praktik. Yogyakarta:Ar-Ruzz Media.

Bass, Bernad M. dan Ronald E. Riggio. (2006).Transformative Leadership. The United States Of America: Lawrence Erlbaum Associates, Inc.

Bogdan, Robert C. dan S.J. Taylor. (1975). Introduction to Qualitative Research Method a PhenomenologicalApproach the social. New York:Jhon Wiley.

Danim,Sudarwin. (2006).Visi Baru Manajemen Sekolah. Jakarta: Bumi Aksara.

Indarti, Luluk.(2017). Dimensi-Dimensi Kepemimpinan Transformatif Pendidikan Islam.Ta'allum: Jurnal Pendidikan Islam, 5 (1), 21-36.

Komariah, Aan dan Cepi Triatna. (2006).Visionary Leadership Menuju Sekolah Efektif, Jakarta: Bumi Aksara.

Milles, Mathew B. dan A. Michael Huberman. (2005).Qualitative Data Analysis, diterjemahkan oleh Tjecep Rohendi, Analisis Data Kualitatif: Buku tentang Metode-Metode Baru,Jakarta; UI Press.

Muhaimin, et.al. (2009).Manajemen Pendidikan Aplikasinya dalam Penyusunan Rencana Pengembangan
Sekolah/Madrasah,

Jakarta:

Prenadamedia Group.

Musfah, Jejen. (2017).Manajemen Pendidikan, Teori Kebijakan dan Praktik,Jakarata: Kecana.

Rusdianto. (2015). Interaksi Neurosains Holistik dalam Perpektif Pendidikan dan Masyarakat Islam. Hunafa: Jurnal Studi Islamika, 12 (1), 71-94.

Sandberg, J. (2000). Understanding human competence at work: An interpretative approach. Academy of Management Journal, 43(1), 9-25.

Sanimbar Mustafa \& Andi Anira. (2016). Pola Komunikasi Kepemimpinan Kepala Madrasah dalam Mengelolah Pembinaan Akhlak Peserta Didik pada Madrasah Aliyah Negeri 2 Model Palu. Istiqra: Jurnal Hasil Penelitian, 4 (2), 265-287.

Setiawan, Bahar Agus et.al. (2013)TransformativeLeadership Ilustrasi di Bidang Organisasi Pendidikan,Jakarta: Raja Grafindo Persada.

Spencer, L. M., \& Spencer, P. S. M. (2008). Competence at Work models for superior performance. John Wiley \& Sons.

Susanto, Ahmad. (2018). Manajemen Peningkatan Kinerja Guru, Konsep, Strategi dan Implementasinya,Depok: Prenada Media Group.

Undang-Undang Nomor 20 Tahun 2003 Tentang Sistem Pendidikan Nasional

Zwell, M. (2000). Creating a culture of competence. Wiley. 